Niyazova A.E. ${ }^{1}$

${ }^{1}$ Al-Farabi Kazakh National University

\title{
SOCIAL AND PSYCHOLOGICAL FACTORS OF PSYCHOLOGICAL WELLBEING IN HIGHER EDUCATION SYSTEM OF KAZAKHSTAN
}

\begin{abstract}
The article investigates the relationship of psychological wellbeing and success in the professional activity of the person. Despite the fact that psychological wellbeing comes out as mainly psychological term, particularly in case of studying the employees of universities it turns to its sociological side. Due to the fact that any kind of communication is close to sociological stream and some issues in the used questionnaires reflects the sociology as well. The understanding of term success in this work turns to the concept of stress resistance and a willingness and readiness for change of the people who are professionals in the field of education. To be more precise, those who are the teaching staff of the national universities. The introduction part suggests brief historical data about the development of the term of 'psychological wellbeing. The relevance of the article is determined by the need to establish an understanding of the term psychological wellbeing in Kazakhstan, particularly in its educational system. As well as the reorientation of the work of the psychological trend in practically meaningful and relevant channel. In this article, it was suggested to analyze the psychological wellbeing as a set of objective factors derived in the appropriate scales. In addition, measurements of stress level were carried out as the main indicator of success in the professional activity of the subjects, to determine the most obvious among the parameters of psychological wellbeing of the physiological, emotional, behavioral and cognitive characteristics. The study was conducted as part of the Faculty of Humanities of one of the national universities of Kazakhstan, taking into account all its member department. Identify the general level of prosperity and the degree of stress on a sample of employees of this department. The importance of this work is due to the practice-oriented approach to the study of the structure of organizations and identify the causes of low productivity of staff borrowed from foreign practices. The basis of such practices include a thorough study of the individual and private organizations (in this case, the Faculty of Humanities of National University).During the research psychological wellbeing scales by K.Riff" and the questionnaire on stress resistance by L.Loginovoy were used. The results from the methods revealed interesting figures. Both from the analysing the results from each of the methods seperately and while watching the correlation between them. The article includes detailed conclusions for each of the departments and the provision of specific data.
\end{abstract}

Keywords: psychological wellbeing, sociological factors, stress, stress resistance, change on the working place.

\section{Ниязова A.E. ${ }^{1}$}

${ }^{\perp}$ Әл-Фараби атындавы Қазақ ұлттық университеті

\section{ҚАЗАҚСТАННЫН ЖОҒАРЫ БІЛІМ БЕРУ ЖУЙЕСІНДЕГІ ПСИХОЛОГИЯЛЫҚ ӘЛ-АУКАТТЫН ӘЛЕУМЕТТІК-ПСИХОЛОГИЯЛЫК ФАКТОРЛАРЫ}

\section{Аң̧датпа}

Мақалада психологиялық салауаттылық пен адамның кәсіби қызметіндегі сәттіліктің байланысы қарастырылған. Психологиялық сауықтыру термині негізінен таза психологиялық тамыры бар екеніне қарамастан, жоғары оқу орындарының қызметкерлерін зерделеу кезінде оның әлеуметтанулық компоненттерін ажырату орынды. Сонымен қатар, байланыстың кезкелген түрін зерттеу, сонымен қатар кейбір сауалнамаларды қолдану социологиялық негізге ие.

Егер біз сәттілік туралы толығырақ түсінуге бет бұратын болсақ, онда осы жұмыс аясында оған стресске төзімділік және өзгерістерге дайын болу сияқты компоненттер кіреді, тікелей білім саласындағы кәсіптермен адамдармен. Дәлірек айтсақ - ұлттық университеттердің 
профессорлық-оқытушылық құрамы. Кіріспе бөлім психологиялық салауаттылықтың қалыптасуына жан-жақты тарихи шолуды қамтиды. Келесі келген мақаланың маңызды бөлігі Қазақстандағы психологиялық әл-ауқат, нақтырақ айтқанда оның жоғары оқу орындары жүйесінде түсінікті қалыптастыру мәселесі. Сонымен қатар, оның әлеуметтік және психологиялық құрамдас бөліктерін іс жүзінде маңызды бағытқа қайта бағыттау ұсынылады.

Бұл мақалада психологиялық әл-ауқат тұжырымдамасын объективті факторлардың жиынтығы ретінде қарастыруға болады. Психологиялық салауаттылық факторларымен неғұрлым дәл арақатынасты анықтау үшін стресске төзімділікті анықтау параметрлері жекежеке субъектілердің физиологиялық, эмоционалды, мінез-құлық және танымдық сипаттамаларында жетістікке жетелейтін жетекші индикатор ретінде алынды.

Жұмыс Қазақстанның ұлттық университеттерінің бірінде, гуманитарлық факультетте, оған кіретін барлық кафедраларда жүргізілді. Осы мақаланың маңыздылығы батыстық тәжірибеге негізделген ұйымдық құрылымды зерделеуге және қызметкерлердің еңбек өнімділігінің төмен болу себептерін анықтауға бағытталған. Мұндай тәжірибенің негізі әр ұйымды мұқият және жеке зерттеу болып табылады (бұл жағдайда жеке оқытушылар құрамы және 6 кафедра).

Зерттеу барысында келесі сауалнамалар пайдаланылды: К.Риффтің психологиялық саулығының ауқымы және Л.Логинова стресске қарсы тұру туралы сауалнама. Зерттеу нәтижелері сауалнамаларды жеке өңдеуде де, олардың ара қатынасын қарастыруда да қызықты қорытындыларды көрсетті. Мақалада әр бөлім үшін толық тұжырымдар мен ұсыныстар берілген.

Түйін сөздер: психологиялық әл-ауқат, әлеуметтік факторлар, стреске төзімділік, стресс, жұмыс орнын өзгерту.

Ниязова A.E. ${ }^{1}$

${ }^{l}$ Казахский национальный университет имени аль-Фараби

\section{СОЦИАЛЬНО-ПСИХОЛОГИЧЕСКИЕ ФАКТОРЫ ПСИХОЛОГИЧЕСКОГО БЛАГОПОЛУЧИЯ В СИСТЕМЕ ВЫСШЕГО ОБРАЗОВАНИЯ КАЗАХСТАНА}

Аннотация

Статья рассматривает взаимосвязь психологического благополучия и успешности в профессиональной деятельности человека. Несмотря на то, что фундаментально термин психологического благополучия имеет сугубо психологические корни, в случае изучения работников высших учебных заведений - уместно разглядеть его социологические составляющие. В добавок изучение любого вида коммуникаций а так же использование некоторых опросников имеет все же социологическую базу. Если же обратиться более детально к пониманию успешности - то в рамках этой работы он вбирает в себя такие составляющие как стрессоустойчивость и готовность к переменам, непосредственно у людей профессий сферы образования. Если быть более точными - преподавательский состав национальных университетов. Вводная часть включает в себя емкий исторический обзор образования самого термина психологического благополучия. Далее идет значимая часть самой статьи в вопросе установления понимания психологического благополучия в Казахстане, а именно в его системе высших учебных заведений. Более того предложена своего рода реориентация его социальных и психологических составляющих в своей сфере в более практически значимом направлении. В данной статье предложено рассматривать понятие психологического благополучие как набор обьективных факторов обусловленных соответствующими шкалами. Так же отдельно были взяты параметры определения стрессоустойчивости как ведущий показатель успешности в профессиональной деятельности испытуемых в их физиологической, эмоциональной, поведенческой и когнитивной характеристиках для выявления более точных корреляций с факторами психологического благополучия. Работа проводилась в одном из национальных вузов Казахстана гуманитарного факультета включая все кафедры входящие в него. Значимость данной статьи заключается в практико ориентированный подход к изучению организационной структуры и идентифицирование причин низкой продуктивности сотрудников на основе западных практик. Основой таких практик является тщательное и индивидуальное изучение 
каждой организации ( в данном случае отдельно взятого факультета и 6 кафедр). В ходе исследование были использована следующие опросники: шкала психологического благополучия К. Рифф и опросник на стрессоустойчивости Л. Логиновой. Результаты исследования показали интересные заключения, как в отдельной обработке опросников так и в рассмотрении их корреляций. Статья включает детальные заключения и рекомендации для каждой кафедры.

Ключевые слова: психологической благополучие, социологические факторы, стрессоустойчивость, стресс, смена рабочего места.

\section{Introduction}

The interest in studying the psychology of wellbeing has arised from the current position of the educational system of Kazakhstan .This is the issue of the globalization process which opened the boarders to many countries and gave the abilities to observe and get acquaintened with the worldwide practices. Republic of Kazakhstan joined the European Higher Education Area (the Bologna Process) in March 2011. Currently, 60 universities of Kazakhstan signed the Great Charter, including the alFarabi Kazakh National University as well. By signing this document the following points were committed:

- development of autonomy of universities;

- democratic principles of management;

- academic freedom of students;

- freedom of scientific research.

Another side of following the Bologna process is about all the dissertation themes that now have to be actual not only within the country but within the whole world. They must face the modern tendencies and reflex the global questions. No matter what the discipline is. There is one specific problem; psychology as science in post-soviet countries differs much from the western ones in methodology: which means that the basic concepts of studying psychology have absolutely opposite character. However, this challenge gives opportunity to dig deeper into the knowledge of Psychology and introduce some new terms, concepts and theories to the Kazakhstani psychology. Due to the up above reason, it was decided to study, introduce and implement the term of psychological wellbeing to Kazakhstan. Moreover, it is a fact there is a growing number of longitudinal studies of wellbeing scales .They are widely used to predict outcomes, for example, longevity, physical health, quality of life, criminality, drug and alcohol use, employment, earnings and pro-social behavior. However, the bigger use of wellbeing scales refer to improve the productivity of employees in the organizations by avoiding the stressful atmosphere and building up healthy organizational cultures.

It is necessary to begin the main theoretical part of the research with the history and definitions of psychology of wellbeing. Because knowing the historical background to the study of wellbeing is necessary to the definition of wellbeing. Two approaches emerged the hedonic tradition, which accentuated constructs such as happiness, positive affect, low negative affect, and satisfaction with life and the eudaimonic tradition, which highlighted positive psychological functioning and human development. However, despite the differences in approach, most researchers now believe that wellbeing is a multi-dimensional construct. Consequently, the diversity of dimensions has created a confusing and contradictory research base. Below there is a summary of some main concepts throughout the history that would help to clarify and point out the main ideas of wellbeing:

- An early attempt to define wellbeing was Bradburn's (1969) classic research on psychological wellbeing. His model specified that: an individual will be high in psychological well-being in the degree to which he has an excess of positive over negative affect and will be low in well-being in the degree to which negative affect predominates over positive [1].

- Carol Riff who is counted to be the main founder of modern wellbeing scales, believe that: subjective well-being consists of three interrelated components: life satisfaction, pleasant affect, and unpleasant affect [2].

- Shin and Johnson (1978) seemed to move closer to defining wellbeing by stating that it is ,a global assessment of a person's quality of life according to his own chosen criteria which is a broad ranging concept affected in a complex way by the person's physical health, psychological state, personal beliefs, social relationships and their relationship to salient features of their environment (World Health Organization, 1997) [3]. 
- The work of Keyes has led to the use of the terms 'flourishing' and 'languishing'. This consider wellbeing to be: as more than just happiness. As well as feeling satisfied and happy, well-being means developing as a person, being fulfilled, and making a contribution to the community [4].

- Seligman states: Well-being theory denies that the topic of positive psychology is a real thing; rather the topic is a construct - well-being - which in turn has several measurable elements, each a real thing, each contributing to well-being, but none defining well-being [5].

- Headey and Wearing believed that ,for most people, most of the time, subjective well-being is fairly stable. This is because stock levels, psychic income flows and subjective well-being are in dynamic equilibrium; Concretely, equilibrium comprises the following themes: physical well-being, plenty of physical resources; absence of fatigue; psychological well-being and evenness of temper; freedom of movement and effectiveness in action; good relations with other people [6].

It can be concluded that the main concept of wellbeing is quite complex and there is a difficulty that researches have been driven by dimensions and descriptions rather than definitions of wellbeing. In order to move closer to a modern definition of wellbeing, we should focus on the thing that mainly it depends on the objective (external) factors; that psychology of wellbeing is the comprehensive term which by the way should cover the specifics of a country (mentality, culture and norms).

The research itself watches the interrelation of psychological wellbeing and success at the working activity. The Republic of Kazakhstan is the growing and developing country with the high potential, great resources and rich history. What it lacks is the well-analysed and concluded concepts of treating people at working places, especially in governmental bodies. There are rooms for strong objectives, abilities and desire to owe the highest competencies and become highly competitive and well-known country. However just a small part regards the human being themselves: their "routine" happiness. There is a strong believe that human capital is not just the resource of getting money. There is much more about the internal motivation of human beings and their self-actualization and satisfaction. Generally saying the aim of the research is to find out the best combination of conditions and competencies in order to make people feel happy and satisfied at the working activity, which would certainly lead to the increase in the incomes and will show dynamics in the whole development of the country. Especially in the times of a crisis this is an opportunity to face changes and turn the employment systems to the right direction. Here it has to be mentioned that the dissertation work turned into the direction of Business Psychology. The idea was fully developed after visiting and discussing the thesis with the Western tutors while the summer courses In Riga, Latvia. It was also found out that the most actual "trends" in Business Psychology for present times is the studies on Change Management and Stress Management. These two concepts became the fundaments in understanding the Successfulness in the professional activity. Under Stress management, the Stress Resistance was identified as the main feature of coping the stress. Later in the paper, the concrete method will be described. Under change management - the reaction and readiness for the change is studied. European practices show us the absolute different way of studying and improving the successfulness of the employees. First of all the studies take place only on individual basis. The specialist get the request on a particular problem from the concrete organization; enters the organization and studies the culture of it and after provide it with deep and thorough research by conducting the interviews and questionnaires and any other kinds of research in order to get the purest results and clear and holistic picture of the organization. The hint is that there is no universal model for each organization. Otherwise it will become just theory.

It was decided to conduct the research in the frames of one of the national universities of Kazakhstan. As it would be quite complicated to take under the research all the faculties, the decision was to take one of the humanitarian faculties and conduct the research by taking into consideration all the six departments within it. According recent statistical data the faculty is considered as the organization with the claim on low indicators of the work loads of the employees. Important note here is the turning point of the whole university due to the changes in the entire Educational system in Kazakhstan. The biggest part of the teaching staff feel confused because of it. The research itself is the try to use the western practices on Kazakhstani market; and the try to improve the current situation within the faculty.

\section{Methods}

It was mentioned earlier that the whole work has practice oriented character, which means it is worked out on the individual bases and has Western content and idea. Due to these reasons all the 
methods of this work are taken from the Western scientists as well. However, for the survey itself translated into Russian language and adopted versions were used.

1. Stress resistance by L. Loginova.

2. The Scales of Psychological Wellbeing introduced by Dr. Carol Riff, which was translated and adopted to the Russian language by T. Shevelenkova and T. Fesenko.

3. Questionnaire on Change by William R. Miller, Theresa B. Moyers, and Paul Amrhein.

Subjects

The entire number of participants is 60 from Almaty, Kazakhstan. 10 participants from each department of National University. Primarily the 5 of which are the employees of younger age (25-40 years old) and 5 of which are those of the elder age ( 40 and elder). For the pilot version the analysis were done on the half of the respondents ( 33 respondents). It must be mentioned that the number is quite small because the research itself has more qualitative character; and is directed forward the digging the situation, identifying the real problems and giving the recommendations.

Statistics

Psychological data was calculated in SPSS 15.

Results and discussion.

In this section were included the calculation of the results from 6 humanitarian departments of National University in Almaty, Kazakhstan. We do not mention exact university because the research was conducted anonymously. In order to exclude exact name of departments they was numbered.

Results of Department \#1.

According to table \#1 there are 7 negative correlations on scales of psychological wellbeing with the emotional and cognitive reactions of the teaching stuff. Being more precise there are reverse effects of emotional reactions with the scales of wellbeing, positive relations with others, self-acceptance and affect balance. Which means that high emotional reactions on the working place, such as irritability with temper tantrums, indifference, the feeling of constant anguish and depression, increased anxiety, the feeling of loneliness, guilt and dissatisfaction, effect on lower wellbeing level; show less positive relations issues with other members of the department; correlates negatively with the characteristics of the self acceptance scale; and, finally, reduces the affect balance or in other words reduces the abilities and understandings of the self assurance and confidence, acknowledgement of the self strength of teachers. Including the opposite results, when the high scores and results of these scales would show the lower or less intensive emotional reactions on the working place. Moving further there are also negative correlations between the cognitive reactions such as concentration, decrease in the process of memorizing, pointing out unuseful issues several times, lack in decision making processes and negative thoughts prevalence, with the scales of wellbeing environmental mastery and human as an open system. So that low cognitive reactions of the stuff show the low level of wellbeing; negatively affects the abilities in managing everyday affairs, changing surrounding context and lacks sense of control over external world; decreases the ranks of the man as an open system scale. Certainly, the vice versa connection have place; the higher the rates of these three scales the better the cognitive abilities of the teachers are.

Table 1 Correlations on scales of psychological wellbeing (Department \#1).

\begin{tabular}{|c|c|c|c|c|c|c|}
\hline & Wellbeing & $\begin{array}{c}\text { Positive } \\
\text { relations } \\
\text { with others }\end{array}$ & $\begin{array}{c}\text { Environmental } \\
\text { mastery }\end{array}$ & $\begin{array}{c}\text { Self- } \\
\text { acceptance }\end{array}$ & $\begin{array}{c}\text { Affect } \\
\text { balance }\end{array}$ & $\begin{array}{c}\text { Human as } \\
\text { an open } \\
\text { system }\end{array}$ \\
\hline $\begin{array}{c}\text { Emotional } \\
\text { characteristics }\end{array}$ &,$- 805\left(^{*}\right)$ &,$- 898\left(^{*}\right)$ & &,$- 774\left(^{*}\right)$ &,$- 842\left(^{*}\right)$ & \\
\hline $\begin{array}{c}\text { Cognitive } \\
\text { characteristics }\end{array}$ &,$- 778\left(^{*}\right)$ & &,$- 778\left(^{*}\right)$ & & &,$- 841\left(^{*}\right)$ \\
\hline
\end{tabular}

Results of Department \#2.

According the data no correlations among the scales and reactions were found. However, this does not mean that there are nothing to analyze in this department. The issue might be in the quite small number of the respondents. Still according the data the department shows well structured rhythm of work and clearly defined goals, as well as good relations among the members of the staff and general self confidence of the teachers. 
Results of Department \#3.

According to table \#2 there is very strong negative correlation between the factors of wellbeing scale and the behavioral characteristics on the working place (by L.Loginova). Which states that the teaching staff who got the highest results on environmental mastery scale owe competence in managing the environment; controls complex array of external activities; makes effective use of surrounding opportunities; able to choose or create contexts suitable to personal needs and values. Low scores means a person has difficulty managing everyday affairs; feels unable to change or improve surrounding context; is unaware of surrounding opportunities; lacks sense of control over external world. Negative correlation logically points to the fact that this kind of test is reduced negative behaviors $(\mathrm{p} 0,01)$ reaction. And vice-versa. It also states that this may cause the increased behavioral reactions among the respondents.

Table 2 Correlations on scales of psychological wellbeing (Department \#3).

\begin{tabular}{|l|l|l|l|}
\hline & Wellbeing & Environmental mastery & Life meaningness \\
\hline Behavioral characteristics & $-1,000(* *)$ & $-1,000(* *)$ & $-1,000(* *)$ \\
\hline
\end{tabular}

Results of Department \#4.

According to the table \#3 there are two positive correlations between the personal grpwth and purpose in life scales with the emotional and behavioral reactions of the teaching staff of the department \#4. Main values within the department are goals in life and a sense of directedness as well as holding beliefs that give life purpose, and, globally, aims and objectives for living. These factors regarding the scale of purpose in life scale. Taking the personal growth scale teachers of this department value most the feeling of continued development, sees self as growing and expandingis open to new experiences, have sense of realizing his or her potential, they see improvement in self and behavior over time and are changing in ways that reflect more self-knowledge and effectiveness. In other words the members of this teaching staff need to know exactly what they do and what is a real importance of it. That is why these parameters correlates closely with the emotional reactions. Actually, in the same way might be explained the behavioural reactions such as increase of the mistakes while the working hours, loss of the attention, distraction of the sleep or appetite , increase in addiction ranks ( cigarettes or alcohol), frequent quarrels and conflicts at the working place and some other matches. Positive correlation means that the better the results or ranks of the scales the better are the reactions. The worse the values are satisfied the worse comes out the results of the emotional and behavioural reactions on them.

Table 3 Correlations on scales of psychological wellbeing (Department \#4).

\begin{tabular}{|l|c|c|}
\hline & Personal growth & Purpose in life \\
\hline Emotional characteristics & &, $857\left(^{*}\right)$ \\
\hline Behavioral characteristics &, $880\left(^{*}\right)$ & \\
\hline
\end{tabular}

Results of Department \#5.

According table 6 there are very strong positive correlation among the scales of wellbeing, positive relations with others, autonomy, personal growth and life meaningness with the behavioral; characteristics. In addition, there is a positive correlation of the autonomy scale with the emotional reaction. Such a strong connection of the behavioral respond to the five scales might be due to the reason that the member of the staff mostly want or like to respond on each working issue by behavioral characteristics. The scale of autonomy requires more thorough description as it calls for meaningfull reaction from the teachers. High scores indicates self-deternance and independence, ability to resist social pressures, to think and act in certain ways; regulation of the behavior, self-evaluation by personal standards. Probably, such reactions are the results of the dissatisfaction and lack acknowledgement from the side of other departments. The sense of competition among the departments within one faculty is normal rank. It might be that the department \#5 lacks the recognition, because the scales that showed correlation are basically all about this issue. This is a desire to build up the friendly and comfortable relationships, being sure and feel confident in the goals and objectives, present is accepted as 
meaningful, there are beliefs that give meaning to life. According to the scale of life meaningness this is also important for the staff to evaluation themselves as being purposeful. In the opposite side they also determine the lack or total absence of meaning of life, past and present are perceived as meaningless, the might feel sense of boredom and pointlessness of existence. Start suffering in case of lack of visible prospects in life, which would have sufficient appeal to the respondent. All these parameters mostly are interpreted in the frames of each department. However, high scores in quite similar in their nature scales show that this might be something that overcomes these borders. Another point of view is that the situation close to the description of the previous department. That actually all these characteristics are so important and calls for the reactions because they are highly ranked.

Table 4 Correlations on scales of psychological wellbeing (Department \#5).

\begin{tabular}{|c|c|c|c|c|c|}
\hline & Wellbeing & $\begin{array}{c}\text { Positive relations } \\
\text { with others }\end{array}$ & Autonomy & $\begin{array}{c}\text { Personal } \\
\text { growth }\end{array}$ & $\begin{array}{c}\text { Life } \\
\text { meaningness }\end{array}$ \\
\hline Emotional characteristics & & &, $814\left(^{*}\right)$ & & \\
\hline Behavioral characteristics &, $926(* *)$ &, $925(* *)$ &, $939\left(^{* *}\right)$ &, $928(* *)$ &, $926(* *)$ \\
\hline
\end{tabular}

Results of Department \#6.

According to table \#5 is only one positive correlation on scales of positive relations with others and its response on the emotional characteristics of the respondent, this means that the higher the scores ( warm, satisfying, trusting relationships with others; being concerned about the welfare of others; capabiliy of strong empathy, affection, and intimacy; understands give and take of human relationships) of the teaching staff of this department the higher the emotional reactions on the working place. Logically, the lower the scores (few close, trusting relationships with others; finds it difficult to be warm, open, and concerned about others; is isolated and frustrated in interpersonal relationships; not willing to make compromises to sustain important ties with others) the lower the reactions. It also might mean that staff from this department can emotionally react (also can demonstrate their negative emotions) on each problems even they have positive relations with others.

Table 5 Correlations on scales of psychological wellbeing (Department \#6).

\begin{tabular}{|c|c|}
\hline & Positive relations with others \\
\hline Emotional characteristics &, $975(* *)$ \\
\hline
\end{tabular}

\section{Conclusion}

National Universities in Kazakhstan differ much from the private ones. The educational system of them is mostly saved from the 'soviet Union times. The main problem is that time has changed significantly but the systems and structures still from that times. Although, externally they do follow the modern worldwide "rules". What is also important is that national universities are huge and even giant in their sizes. Again, this is much easier for the private usually narrow specialized universities. Much more complicated to lead and control such a machine that consist from the various specialties big amount of employees and even bigger amount of students. Finally, it happens to become something extremely heavy and less mobile. It requires a lot of energy and work to systematize it from the beginning and stay up. There are two main difficulties that lead from this. First one, is the globalization conditions- if it won't be able to match the global level then no one would count with such educational system. The second, inner reason, is that students the future generation suffer from this. Kazakhstan has important strengths such as highly qualified fundamental support in the face of strong scientists and teaching staff and many young people who want to join this system. However, due to some reasons this system can not switch on the full power and start to work properly. One of the aims of this research was to try to find out which are the reason. Taking only one faculty for such crucial analysis is not enough. This is more like an introductory and experimental part of the full work. It combines all the western practices and modern trends in order to find out the reasons. 
1. Alkire, S. Dimensions of human development. World Development, 2002. 30, 181-205. http://dx.doi.org/10.1016/S0305-750X(01)00109-7

2. Beaumont, J. Measuring national well-being - Discussion paper on domains and measures. Newport: Office for National Statistics, 2011.

3. Bradburn, N. The structure of psychological well-being. Chicago: Aldine, 1969.

4. Brickman, P. D., \& Campbell, D. T. Hedonic relativism and planning the good society // M.H. Appleby (Ed.), Adaptation-level Theory New York: Academic Press, 1971, P. 287-302.

5. Christopher, J. Situating psychological well-being: Exploring the cultural roots of its theory and research. Journal of Counselling \& Development, 1999. 77, $141 \mathrm{p}$.

6. Keyes, C. L. M., Shmotkin, D., \& Ryff, C. D. Optimizing well-being: The empirical encounter of two traditions. Journal of Personality and Social Psychology, 2002. № 82, P. 1007-1022. 